\title{
ANALYSING THE COMPARATIVE ADVANTAGES OF THE INTERNATIONAL OIL TRADE: THE CASE OF GULF COOPERATION COUNCIL
}

Several studies have investigated the competitiveness with a focus placed on the Middle East, however, there are relatively few to pay attention specifically on the comparative advantages in oil trade. This paper utilizes the Balassa indices to shed light on the general tendencies and specific shifts in revealed comparative trade advantage of the Gulf Cooperation Council member states in main oil products between years 2000 and 2015. Based on our result, only four out of six GCC member states (Kuwait, Kingdom of Saudi Arabia, United Arab Emirates, Qatar) were found to possess an initial competitive status for at least one oil product. A tendency of generally diminishing comparative advantage in oil trade for the GCC group was revealed as a consequence of economic, financial, political reasons, including the aftermath of the financial crisis, regional instability, the Syrian conflict, fluctuating international oil prices.

\section{Keywords: Gulf Cooperation Council, oil trade, comparative advantage}

$\mathrm{I}_{\mathrm{s}}^{\mathrm{t}}$ did not take much time after the publication of Adam Smith's 'The Wealth of Nations', until another economist, David Ricardo (1772-1823) appeared on the horizon of modern classical economics, making an impact on the classical economic theory of international trade by further developing Smith's ideas and bringing existing theories closer to depicting reality.

According to Ricardo's theory of comparative advantage, trading can take place even if one country has an absolute advantage over the other in the production of both of two selected goods, because these advantages are not equal, therefore, the country with worse production conditions will still have a comparative advantage in one of the goods and the level of general well-being will rise (Acin, 1974, p. 46-47.).

As a result, a country will export products that it can produce at a low opportunity cost (in terms of other goods that could be produced within the country), while it will import those goods which it can produce only at a comparative disadvantage or slight comparative advantage (Bernstein, 2008).

There is no commonly accepted approach to defining competitiveness or competitive advantage. Certain authors analyse national level competitiveness while others suggest its application at different aggregated levels (Somogyi, 2009).

A number of studies have been conducted about competitiveness in general with a focus placed on the Middle East, however, there are relatively few to concentrate specifically on the combination of competitiveness and comparative advantages in oil trade.

Huggins et al. (2016) embrace a general approach to regional competitiveness, using World Competitiveness Index of Regions (WCIR) as an analysis framework. Authors found that the competitiveness of some Middle Eastern regions undoubtedly stems from the presence of valuable natural resources, however, some others achieved it through other means.

With full dedication to the oil sector, AlQudah et al. (2016) focused on the evaluation of the impact of oil on the global competitiveness of the GCC (Gulf Cooperation Council) states by using panel data techniques. The au- thors observed that competitiveness grows parallel with the increase in oil prices and share of the mining sector in GDP, for the examined countries are heavily reliant on oil sector to achieve and sustain competitiveness. As a result, diversification efforts are bound to lead to a decrease in comparative advantage and trigger a tendency of diminishing competitiveness.

Finally, Almas and Hajiyev (2013) prepared an analysis of the existing and potential comparative advantages of the Azerbaijani trade, looking at a variety of goods from different sectors. The authors took a close look at the study period between 2007 and 2009 and two RCA indicators, the Balassa and Net Export Ratio indices were used to identify comparative advantages on a wide range of goods including agricultural products, oil products, chemicaland petrochemical products, as well as machineries. The outstandingly high numbers for the two indices both suggest that Azerbaijan had a robust comparative advantage in crude oil within the study period.

Throughout our research it became clear that there are no previous studies with an analysis arrangement identical or even similar to the one selected for this paper, therefore, it is reasonable to conduct research on this topic, along with the lines and with the help of the tools discussed earlier.

\section{Methodology}

The modern basis of calculating comparative advantages, the so-called 'B' index was invented by Balassa (1965) and published in his famous study 'Trade liberalization and revealed comparative advantage'. Since then, it has been surrounded by vivid interest, and for a handful of limitations have been revealed in relation to it, several economists felt inspired to extend and improve it further in the following decades, too.

The B index gives researchers a hand to compute the relative comparative advantage or disadvantage for a product or group of products, compared to industry or the export market. It proposes to compute revealed comparative advantage as follows:

$$
R C A i j=B i j=(X i j / X i t) /(X n j / X n t)
$$


where X stands for export volume, $\mathrm{i}$ and $\mathrm{j}$ represent a selected country and product respectively, while $t$ and $n$ stand for a certain product group and a group of countries, respectively (Balassa, 1965).

In theory, the index can take values from 0 to positive infinity. According to Balassa, an end result above 1 suggests that the selected country enjoys comparative advantage with respect to the selected product over fellow suppliers, therefore, it is bound to be manifested in high export market share. In turn, an end result between 0 and 1 implies comparative disadvantage for the selected country in contrast to fellow suppliers, which translates into low export market share.

The Balassa (1965) index was found to have some limitations (discussed later), which encouraged economists to elaborate tools which depict reality about comparative advantages in a more accurate way. Without any changes in the B index formula, Hinloopen - van Marrewijk (2001) proposed a classification system, which helps in properly evaluating the end results. The authors labelled their established categories as follows:

$$
\begin{aligned}
& \text { Category } A: 0<B \leq 1, \\
& \text { Category } B: 1<B \leq 2, \\
& \text { Category } C: 2<B \leq 4, \\
& \text { Category } D: 4<B,
\end{aligned}
$$

where products with no comparative advantage belong to category A, while products with weak, moderate and strong comparative advantage are assigned to category B, C and D, respectively. This classification contributes to the proper interpretation of B index values; however, it does not solve the problem of the lack of proportionality mentioned above.

The B index has quickly gained popularity and it has been widely used by many to evaluate trade advantage positions and prospects. Nevertheless, throughout the decade long use of B index, it became evident that besides its positive features of simplicity and ease of use, there are some limitations to it, too.

Foreign trade is known for being a highly significant area of national economic policies, therefore, attempts from governments to achieve certain changes in national foreign trade structure in shape of direct interventions (subsidization of certain industries) or restrictions are likely to be influential factors in every national economy (Jámbor, 2009). The B index is rightfully criticized for disregarding the impacts of these different economic policies driven by specific national drives, thus Siggel (2006) came to the conclusion that the index is more of a useful tool to capture competitiveness in general than to measure comparative advantages.

\section{Sample and data}

The study period embraces years between 2000 and 2015. All data used for the empirical study are drawn from the World Integrated Trade Solutions (WITS) database of the World Bank (2017). Although the entire 27th chapter of Harmonized System (HS) deals with petroleum and its derivatives, over $90 \%$ of Gulf States' export volume is captured by three of its subcategories, therefore, the scope of this paper is confined to the following three, HS-4 digit product codes: 2709 (Petroleum oils and oils obtained from bituminous minerals; crude), 2710 (Petroleum oils and oils from bituminous minerals, not crude; preparations n.e.c, containing by weight $70 \%$ or more of petroleum oils or oils from bituminous minerals; these being the basic constituents of the preparations; waste oils) and 2711 (Petroleum gases and other gaseous hydrocarbons). Missing values are in all cases substituted by zero values. The objective of the study is to investigate the following two hypotheses:

H1: All GCC member states enjoyed revealed comparative advantage in oil trade within the study period in the World market.

We specify that an initial competitive status means that a country has a comparative advantage during the analysed period for at least one oil product of the three analysed product category (crude oil, oil preparations and petroleum gases).

H2: The level of revealed comparative advantage of GCC member states in oil trade has significantly diminished over the study period due to political and economic reasons.

The $\mathrm{H} 2$ attempt to refer to the impact of the financial crisis in 2008 and its aftermaths, the Syrian conflict and the emergence of renewable energy use. Apart from the interpretation of obtained results, a special emphasis is placed on highlighting the probable influential factors behind major shifts, should they be of economic, political or other sorts of cause.

\section{Pattern of world oil production and trade}

The extraction of petroleum in industrial volumes dates back to the 19th century, and since then, continuous technological improvements made oil industry reach mature industry status. Petroleum consumption heavily damages the environment, while it is not true for the more and more affordable renewal energy, which makes some argue that the end of the oil era is near. However, petroleum did not cease to be the world's leading source of energy, accounting for $32,9 \%$ of global energy consumption in 2015 (BP, 2016). For its utmost importance, we found petroleum suitable to be the commodity of interest for our empirical analysis.

Petroleum is necessary for the functioning of every healthy economy, however, reserves are oddly distributed among countries. In order to let trade happen between those willing to sell and buy, an active international market was established, which is accessible to any interested party. The unit measure of crude oil is barrel, and although it is a relatively homogenous commodity, certain oil markers are in use for price benchmarking worldwide, the most acknowledged of which are the WTI (West Texas Intermediate - high quality, light petroleum with low sulphur content), Brent (a combination of crude oil extracted from fifteen different North Sea oil fields, almost as light as WTI crude) and Dubai-Fateh (medium sour Dubai crude oil) oil types (Mikesy, 2009). NYMEX (New York Mercantile Exchange) and OPEC (Organization of the Petroleum Exporting Countries) Basket of Crudes also serve as oil price benchmarking tools (Lövész, 2006).

International oil price changes are consistently surrounded by vivid interest, and the last sixteen years 
brought about intensive price fluctuations. Two steep price drops occurred since 2000 in years 2008 and 2014. The global financial crisis triggered the sharpest decline seen in the new millennium so far, with a $66 \%$ price drop within one year. The period of recovery and stabilization of crude oil prices around 100 USD/barrel after 2008 was ended by an approximately $50 \%$ decline in 2014 . Lately, oil prices have shown a high level of instability, sinking below 30 $\mathrm{USD} /$ barrel and climbing up to $50 \mathrm{USD} /$ barrel since then.

Such fluctuations may be driven by a multitude of causes, including political events, economic and monetary shocks, natural disasters and as Mikesy (2009) notes, speculation activity which was proved to be one of the most important causes behind the robust price increase between 2000 and 2008.

Table 1 is meant to highlight the ten most influential petroleum producer and exporter countries, whose joint export volume accounts for more than $50 \%$ of total world exports. (For the first glance, the presence of Singapore in the top ten oil exporters may seem to be misleading. Although the country has no remarkable hydrocarbon reserves, it has huge capacities in oil refining, thus with an extremely high value of oil preparations exports (2710), Singapore makes it into the top ten). The Table 1. is below is based on historical oil trade data of World Bank (2017) from 2000 to 2015.

Table 1 World top 10 oil exporters, 2000 and 2015

\begin{tabular}{|l|l|r|r|}
\hline Ranking & Country & \multicolumn{1}{|l|}{ in billion } & Share \\
\hline 1 & Saudi Arabia & 2906 & $13.23 \%$ \\
\hline 2 & Russia & 2476 & $11.27 \%$ \\
\hline 3 & UAE & 1027 & $4.68 \%$ \\
\hline 4 & Canada & 858 & $3.91 \%$ \\
\hline 5 & Norway & 775 & $3.53 \%$ \\
\hline 6 & United States & 762 & $3.47 \%$ \\
\hline 7 & Nigeria & 755 & $3.44 \%$ \\
\hline 8 & Kuwait & 715 & $3.25 \%$ \\
\hline 9 & Venezuela & 658 & $3.00 \%$ \\
\hline 10 & Singapore & 644 & $2.93 \%$ \\
\hline $\begin{array}{l}\text { Top 10 Total } \\
\text { oil export }\end{array}$ & & $\mathbf{1 1} \mathbf{5 8 1}$ & $\mathbf{5 2 . 7 1 \%}$ \\
\hline $\begin{array}{l}\text { World Total } \\
\text { oil export }\end{array}$ & & $\mathbf{2 1} \mathbf{9 7 3}$ & $\mathbf{1 0 0 \%}$ \\
\hline
\end{tabular}

Source: Own calculations based on World Bank (2017) World Integrated Trade Solution database (HS-4 level, product code: $2709-2710$ )

The Kingdom of Saudi Arabia is the world's most important oil exporter, solely accounting for more than $13 \%$ of total world exports. Around $87 \%{ }^{1}$ of Saudi government revenues origins from the petroleum sector, which points at a high degree of demand risk exposure on national levels (Saudi Arabian Monetary Authority, 2016). Saudi policymakers have strived lately for mitigating this exposure, by opening towards renewable energy in the spirit of diversification.

The richest country in hydrocarbons worldwide, Russian Federation occupies the second place in leading oil exporters' list by realizing more than $10 \%$ of world total oil exports alone. Extraction and export of crude oil and natural gas constitute an element of utmost importance for Russia, as it adds up to more than half of the country's federal budget revenue (EIA, 2015). Russia does not only excel in hydrocarbon extraction but is a flagship of nuclear power generation technology, as well as being famous for using its energy source capacities as a basis for negotiations to obtain more favourable positions in the field of international politics.

Occupying the third place in total export volume list, the United Arab Emirates maintains a wise approach towards hydrocarbon reserves. While it has continuously supplied crude oil, money inflow has been utilized for decades to successfully transform this federal state into a touristic and acknowledged financial hub (BBC, 2016b). Its architectural and touristic hallmarks, the widespread image of luxury, in addition to expertise in financial and other sorts of services ensure that the Emirates' position as one of the most attractive welfare states is secured even after the end of the oil era.

Canada is very rich in oil sand reserves, which have gradually become profitable to recover since the $1980 \mathrm{~s}$. Although oil sand recovery raises concern for it heavily damages the environment, Canada is committed to increasing its production volume and expects to become the world's leading oil provider till 2020 (CAPP, 2017).

One of the wealthiest states worldwide, Norway occupies the fifth place in total export volume rank list. Oil reserves discovered at the continental shelf under the North Sea and the Norwegian Sea in the 1960s stabilized Norway's positions as a leading oil producer and exporter. Hydrocarbon exports provide a reliable source of budget income, contributing to achieving and maintaining outstandingly high living standards and national prosperity (Norwegian Petroleum, 2017).

\section{Role of Gulf Cooperation Council in oil trade}

In this study, we selected a group of six countries which are: Bahrain, Kuwait, Oman, Qatar, the Kingdom of Saudi Arabia and the United Arab Emirates.

On one hand, these states are located very close to each other geographically, thus their geological features are very similar. Beginning from the Proterozoic (800-640 million years ago), a sequence of tectonic movements started, paving the way for the generation of the largest part of Middle Eastern hydrocarbon reserves throughout the Mesozoic Era, 252-66 million years ago (Szücs, 2007). As a consequence of these tectonic movements, approximately $30 \%$ of today's proved oil reserves are located beneath the Gulf States (BP, 2016), which makes them rightfully regarded as candidates 
for having high advantage in oil production, as well as being treated as key players from geopolitical perspective.

On the other hand, as a consequence of geographical proximity, these countries have highly similar historical and cultural background. Beginning from the spread of Islam -the most influential, cross border cultural shaping power of the region -, and the political expansion and conquests under its flag in the 7th century A.D., the territory of today's Gulf States has always belonged to the nearest located superpower of the era, should it be the Abbasid Caliphate or the Ottoman Empire in the Middle Ages, or the British Empire in the modern times (Weiss - Green, 1995). In terms of cultural similarity, Islam left its mark on nearly every aspect of the way nations of the Arab Peninsula live, including architecture, clothing, regional traditions and social standards.

During the 20th century, the six selected Arab states realized that uniting their political will and performing joint actions will result in better assertion of their interest by international superpowers, therefore they developed a high level of cooperation in many fields. They are member states of several international organizations, including: the United Nations, the Organization of Islamic Cooperation (which strives for fostering cooperation and solidarity among Islamic states), the Arab League (which constitutes a politics driven regional bloc of Arab states), and the Gulf Cooperation Council, which is the exclusive political and economic alliance of Bahrain, Kuwait, Oman, Qatar, the Kingdom of Saudi Arabia and the United Arab Emirates. Besides deepening the relations between member states, the Gulf Cooperation Council aims at fostering common legislation in numerous fields, unification of corporate culture and synchronizing the efforts put in innovation and technological advancement (GCC, 2017). Furthermore, four states out of six - namely, Kuwait, Qatar, the Kingdom of Saudi Arabia and the United Arab Emirates - are members of the Organization of the Petroleum Exporting Countries (OPEC) since the 1960s', which is definitely the most significant influencer of oil prices in the world market (Lövész, 2006).

\section{Factors influencing GCC's oil trade between 2000 and 2015}

Changes in commodity trade advantages are influenced by a handful of political, economic, historic and other factors, the number of which is constantly increasing with globalization. Beside regional changes it is required to take into consideration every factor which might play a role in the change of tendencies, should they happen in the close neighbourhood or in a geographically remote area.

\section{Political influencing factors}

The Arab Peninsula can be characterized by tranquillity and prosperity within the study period. There were no armed conflicts in the region, except the Yemeni Civil War which began in 2015 (and since it is at the very end of the examined timeframe, it does not have a relevant impact on the results). However, the Middle East as wider environment witnessed a stormy fifteen years since 2000. There have been several bloody conflicts, the most significant of which are the following:
The Iraqi War, which was launched by the United States of America in 2003, driven by the US's eagerness for fighting against terrorism and spreading of democratic values (at least according to the official reasoning). The war lasted for eight years until 2011 and resulted in political chaos after toppling the government of Saddam Hussein (Jáni, 2011).

The Second Intifada, which is concentrated around the Palestinian-Israeli conflict beginning from 2000. It is an ongoing conflict which is characterized by suicide- and missile attacks (Ajluni, 2003).

The Second Lebanon War, which was a 34-day long armed conflict in the summer of 2006, between the forces of Israel and Hezbollah on the territory of South Lebanon. The war caused the death of thousands of soldiers as well as civilians (Tomolya, 2007).

The Arab Spring, which comprises the anti-government protests in many Arab countries in 2011, resulting in the toppling of reigning governments in Tunisia, Lybia and Egypt, among others (Jones, 2012).

The Syrian Civil War, which is an ongoing bloody conflict since 2011. In the beginning, there were only a few parties involved including government forces, the extremist rebels supported from outside the country, and the Kurdish minority forces. From 2014 onwards, additional parties got involved, for example, the Islamic State of Iraq and Levant (IS), and many other small militias (BBC, 2016a).

The appearance of IS terrorist organization in Iraq in 2014, which is a focal point and key cause of bloody battles to this day (BBC, 2015).

Although the above list is far from being complete, it is evident that neighbouring Middle-Eastern societies were suffering from severe armed conflicts within the study period, which definitely had an indirect impact on the price of oil, and through this on the oil exporter states and their competitiveness, too.

\section{Decisive economic influential factors}

The countries of the Arab Peninsula were gifted with prosperity in economic terms between 2000 and 2015, as huge amounts of money flow into the Gulf States because of high oil prices in the 2000s. As a consequence to the rapid increase in national wealth, spectacular investments took place in these countries outside of raw material extraction, and in the spirit of diversification, other industries have also developed, for instance, tourism and banking. Nevertheless, it would be mistaken not to take international economic tendencies into consideration, which had their indirect impact on Gulf economies, too. Some of these decisive economic happenings are as follows:

The rapid growth of the Chinese and Indian economies. The outstanding GDP growth necessary to realize such development implies large energy needs which have a positive effect on oil industry.

The monetary crisis in 2008, which had a worldwide impact on monetary affairs. Nonetheless, as the Gulf States have already been on their way to becoming more reliant on Islamic banking, the unique features of this alternative monetary approach significantly mitigated the effects of the crisis (Ádám et al., 2015). 
The nuclear catastrophe of Fukushima in 2011, which made national leaders rethink their energy policy worldwide (Vivoda, 2012).

The oil price depression in 2014-2015, which brought about a large-scale decrease in crude oil prices, by more than 70\% (Crude Oil Prices, 2017). It is easy to see that oil exporter countries were heavily hit by this change and had to face drastic losses of income.

It is worth mentioning that none of the listed economy related items has direct links to the Middle East, but still, they have their influencing power on the conditions of oil extraction and indirectly, on oil trade advantages of exporter countries.

\section{Oil trade patterns of the GCC countries}

Oil is an element of utmost importance in GCC foreign trade, which significantly influences member states' budget.

Starting with the year 2000, the favourable international market environment and a steadily increasing oil price resulted in a tendency of rising oil export year by year, which was spectacularly broken by the financial crisis, pushing oil export to radically decrease till 2009 (331 billion USD). The years of recovery brought about a tendency of the increase until arriving at the highest observed value of the study period in 2013 (720 billion USD), followed by a drastic decrease in oil export in 2014-2015 (Figure 1).

Figure 1 Oil trade volume for GCC countries between 2000-2015 (in billion USD)

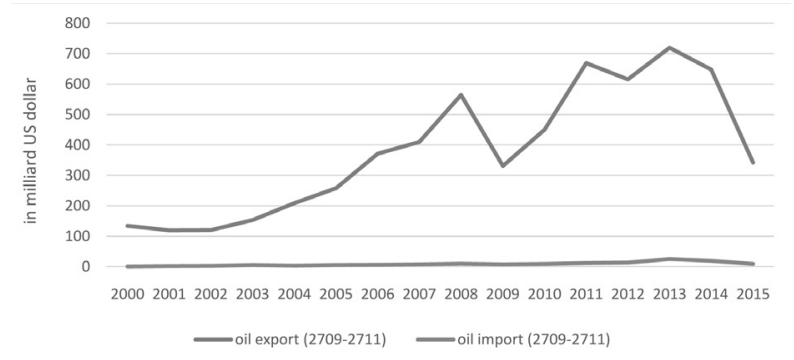

Source: Own calculations based on World Bank (2017) WITS database

It is worthwhile to take a look at the proportion of oil trade to total trade for GCC countries, too. In Figure 2, we can observe a highly positive oil export with a share of oil import below 5\% in GCC total trade during the entire period.

Figure 2 Proportion of oil trade to total trade for GCC countries, 2000-2015 (in percent)

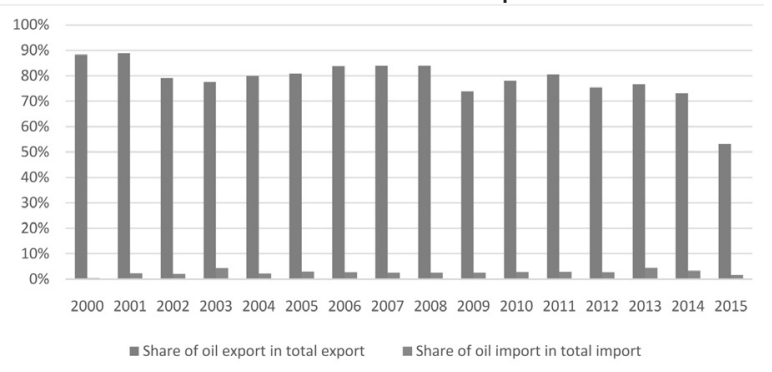

Source: Own calculations based on World Bank (2017) WITS database
The fact that the share of total oil imports is significantly lower than total exports suggests that GCC countries realized a significant export surplus for a period analysed. The only slight decline in exports share in 2009 can obviously be traced back to the effects of the global financial crisis. Import tends to react to market environment changes to a lesser extent than exports does, which is due to the dominance of oil exports in total exports and as a consequence, a high degree of exposure to international oil price fluctuations.

\section{Empirical results}

As mentioned before, Balassa-index is meant to depict the competitiveness and comparative advantage of a certain market player, in terms of given products based on historical trade data. The study period cover (16 years), index values are assigned to the three most important oil product code (27092711). Products under product codes $2709-2711$ are referred to 'crude oil', 'oil preparations' and 'petroleum gases' respectively.

\section{Bahrain}

According to Balassa-index figures, the competitiveness of Bahrain has significantly decreased since 2000 . Even if in the first two years did the measure exceed 1, which is known as the lower limit of international competitiveness, and the situation has just got worse with time, arriving at moderate B values $(0,21)$ after 2011 (Figure 3).

Figure $3 \mathrm{~B}$-index results for oil trade Bahrain

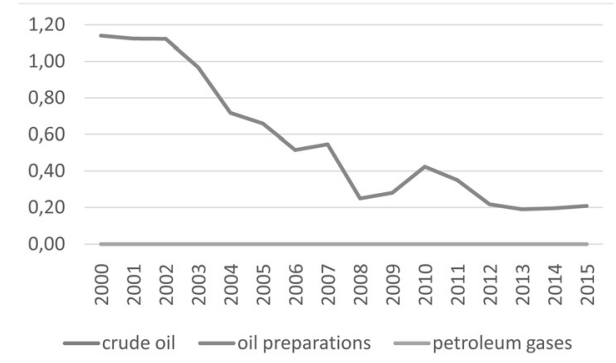

Note: In the case of Bahrain, we have to settle for insufficient export data retrieved from World Bank (2017) WITS database. Most of the export values for crude oil and petroleum gases were missing, and substituted by zero values. Source: Own calculations based on World Bank (2017) WITS database

There are multiple reasons behind the observed pattern of fading competitiveness in oil preparations (2710), including the impacts of financial crisis in 2008 (which resulted in halving of B-index in next year), international oil price fluctuations, the finiteness of national petroleum reserves as well as the lack of putting big enough emphasis on technological developments, letting competitors take over. The loss of revealed competitive advantage in oil trade is only one of the problems Bahrein needs to face currently - increasing public debt levels and constant social unrest (originating from religious stems) constitute major challenges to the country. Nevertheless, the Bahraini economy is not likely to collapse soon, since the country boasts with the Gulf region's most diversified economy. Bahrain's 
governance puts special emphasis on the financial sector, letting the hydrocarbon sector to contribute only $20 \%$ to the GDP (Talal-Azimi, 2016). As a result, any shocks hitting the sector are less harmful to the national economy.

\section{Kuwait}

Looking at trade data and B index, it can be concluded that around the beginning of the new millennium, the country was firmly competitive in crude oil and oil preparations trade. Although the B index value for crude oil trade has dropped by nearly $33 \%$ throughout fifteen years, Kuwait managed to stay near to 1 in terms of competitiveness measure $(1,27$ in 2015), which means the country is still an important crude oil (2709) supplier. However, in terms of oil preparations (2710), figures testify a significant decrease within the study period $(1,6$ to 0,5$)$, meaning B-index nearly shrank to one-third of the initial value and Kuwait lost its international competitiveness. In the field of petroleum gases (2711), Kuwait was not regarded as competitive exporter even around 2000, while its positions only worsened since then (Figure 4).

Figure 4 B-index results for oil trade of Kuwait

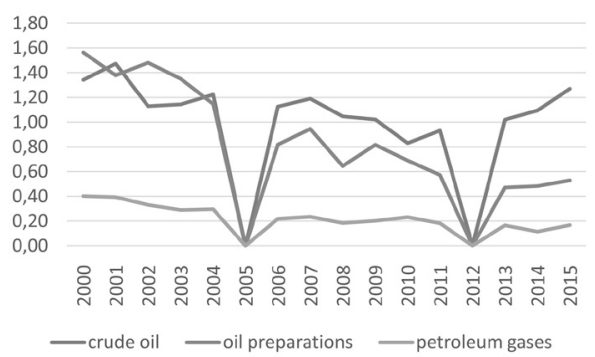

Source: Own calculations based on World Bank (2017) WITS database

The negative tendencies of competitiveness in oil products are a bit surprising in the light of Project Kuwait (a longterm vision of Kuwaiti oil policy, first announced in 1997), Clean Fuels Project (aiming at upgrading national refineries, approved in June, 2011) and other projects launched between 2000-2015, which testify national commitment towards further increasing oil and oil derivatives production to reach 4 million barrels/day until 2020 (sustaining this volume until 2030) as well as increasing natural gas production to reach 4 billion cubic feet per day until 2030 - which equals a 300\% increase compared to the production volume achieved in 2013 (EIA, 2013). Nevertheless, observed downward sloping competitiveness patterns are explainable by the fact that this study concentrates on a timeframe which is regarded as short term in the case of such commitments, while they are expected to yield growth in the long-term only.

\section{Oman}

Possessing small hydrocarbon deposits compared to neighbouring GCC countries, yet the Sultanate of Oman maintains an active hydrocarbon production and trade. The Bindex for crude oil trade (2709) exceeded the lower boundary of competitiveness (1) in 2000 by taking a value of 1,17, however, its competitiveness melt away until 2007, only to report a B-index value of 0,4 (Figure 5). As a joint consequence of new discoveries and the use of enhanced oil recovery (EOR) techniques (EIA, 2016), a tendency of slow recovery has been witnessed, reaching 0,65 by 2015 (Appendix), in spite of the fact that low level of oil price continuously challenges the oil industry and has a negative impact on oil extraction.

Figure 5 B-index results for oil trade of Oman

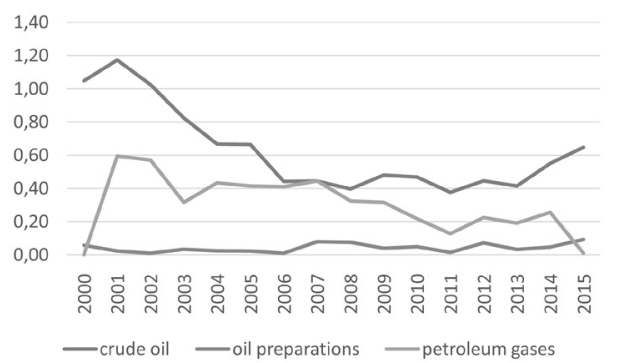

Source: Own calculations based on World Bank (2017) WITS database

Nevertheless, the natural gas sector was the one worst hit by the financial crisis in 2008, as well as a drastic drop of B-values ( 0.26 to 0.01$)$, are observed between 2014 and 2015 (Appendix).

\section{Qatar}

Although Qatar is an important player in the field of crude oil extraction and trade, it is, without a doubt, the most prominent player in the field of natural gas production and export. According to the estimate of BP (2015), 13,1\% of known natural gas reserves are located under Qatari soil in 2015, which is mirrored in Balassa-index results, too. Qatar has been holding its competitive status, managing a duplication in its Bindex value since 2000. The key to its success lies in globally increasing demand for natural gas, regional stability, magnitude and ease of accessibility of reserves, as well as prudent investments in extraction technology. Based on B-index results, Qatar has not been internationally competitive in the fields of crude oil (2709) and oil preparations (2710) within the last fifteen years (Appendix), moreover, it shifted towards competitive disadvantage for reasons similar to those seen at other oil exporter GCC member states (Figure 6).

\section{Figure 6 B-index results for oil trade of Qatar}

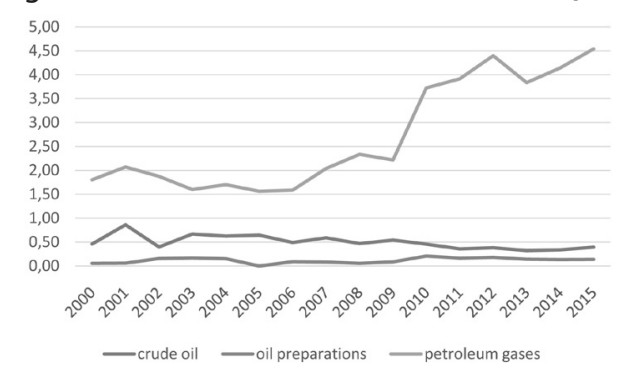

Source: Own calculations based on World Bank (2017) WITS database

\section{The Kingdom of Saudi Arabia}

The Kingdom of Saudi Arabia is worldwide known for its huge petroleum reserves. Although the country did not cease to be a player of utmost importance in the field of oil trade, 
historical data from the last fifteen years suggest that the Saudi comparative advantage in oil trade is diminishing (Figure 7). Throughout the study period, Saudi crude oil (2709) trade has witnessed a little less than fifty percent loss in terms of Balassa-index measure $(7,44$ to 4,82$)$, which was distributed more or less evenly among the fifteen years of interest. Yet, the country exhibits a B value of around 4 between 2010 and 2015. The negative impacts of the global financial crisis in 2008 were not promptly mirrored in Saudi B values, a more significant decrease in comparative trade advantage is only captured in the B values of years 2010 and 2011 (Appendix). The delayed and gradual decrease highlights a positive feature of Saudi oil exports, namely the fact that events and developments outside the industry do not have direct influential power on export levels.

Figure 7 B-index results for oil trade Kingdom of Saudi Arabia

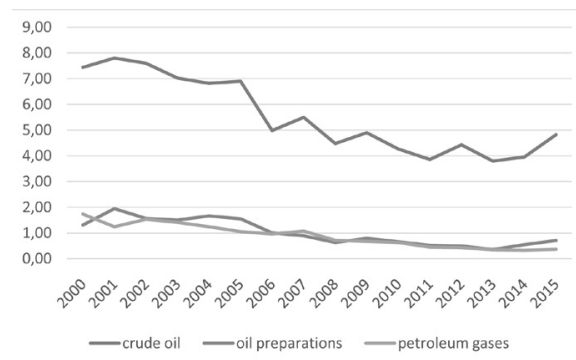

Source: Own calculations based on World Bank (2017) WITS database

As for oil preparations (2710) and petroleum gases (2711), changes in trade volume follow a relatively similar trajectory, starting from above 1,5 in the first third of the study period, arriving at around 0,5 in 2015. This pattern suggests that over fifteen years, Saudi Arabia lost its comparative advantage in exporting these types of goods.

The Saudi economy relies heavily on crude oil exports, which definitely ensure the stability of the national economy in the short term. However, a question mark remains at the long term economic vision of the country, as both industry related and non-industry related factors imply that no economy is viable with an exclusive reliance on oil. On one hand, the exploration of shale oil and advancement of traditional oil extraction technology brings about a larger scale supply and thus a fiercer competition in the market. On the other hand, the generally known worldwide tendencies of shifting towards renewable energy sources and green technologies under the flag of environmental awareness are not working in favour of continuous oil dominance either.

\section{The United Arab Emirates}

Finally, let us take a look at the developments of oil trade advantages for the United Arab Emirates for the study period. Similar to what was observed for the other Gulf States, downward sloping B value is obtained after necessary calculations are performed. Crude oil trade (2709) account for the highest B value $(2,3)$ at the beginning of the new millennium, followed by oil preparations $(1,4)$ and petroleum gases $(0,5)$. All three product categories showed a decrease throughout fifteen years, the degree of which was in parallel to initial value sizes. Crude oil trade B values dropped the most, although still remaining at the 'competitive league' above 1, whereas oil preparations (2710) trade has become comparatively disadvantageous with a final value of slightly more than 0,5 in 2015 . For this product type, the period between 2010 and 2012 was characterized by unprecedented low and disappointing B values, which can neither be explained by political, nor financial reasons (Figure 8). Petroleum gas (2711) trade was not the strongest branch of UAE foreign trade even in 2000 , and in harmony with generally observed tendencies, $B$ values further decreased with time since then.

Figure 8 B-index results for oil trade of the United Arab Emirates

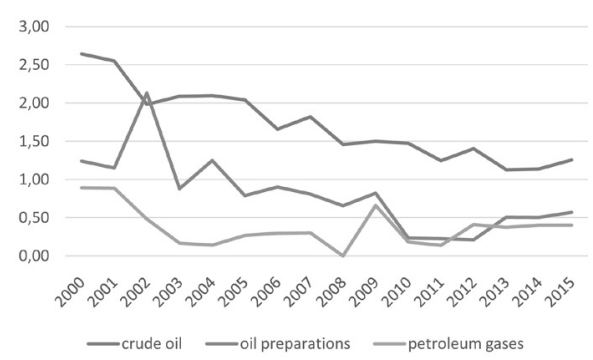

Source: Own calculations based on World Bank (2017) WITS database

Following the instructions of Hinloopen - van Marrewijk (2001), the obtained B values are categorized and shown in details for each year of the study period, as a final step of comparative advantage analysis. The observed distribution of B categories over time seem to confirm the assumptions drawn from independent country analysis about an overall decreasing tendency (share of A categories was increasing) in GCC competitiveness (non-competitive Balassa indices) in oil trade over the course of the study period (Table 2).

Table 2 Frequency of Balassa index category for 6 Gulf countries, over study period

\begin{tabular}{|c|c|c|c|c|c|c|c|c|c|c|c|c|c|c|c|c|c|}
\hline category & 2000 & 2001 & 2002 & 2003 & 2004 & 2005 & 2006 & 2007 & 2008 & 2009 & 2010 & 2011 & 2012 & 2013 & 2014 & 2015 & Total \\
\hline $\mathbf{A}$ & 9 & 8 & 8 & 11 & 10 & 13 & 13 & 13 & 14 & 14 & 15 & 15 & 15 & 14 & 14 & 14 & 200 \\
\hline B & 7 & 7 & 8 & 5 & 6 & 3 & 4 & 3 & 2 & 2 & 1 & 1 & 1 & 2 & 2 & 2 & 56 \\
\hline C & 1 & 2 & 1 & 1 & 1 & 1 & 0 & 1 & 1 & 1 & 1 & 2 & 0 & 2 & 1 & 0 & 16 \\
\hline D & 1 & 1 & 1 & 1 & 1 & 1 & 1 & 1 & 1 & 1 & 1 & 0 & 2 & 0 & 1 & 2 & 16 \\
\hline Total & 18 & 18 & 18 & 18 & 18 & 18 & 18 & 18 & 18 & 18 & 18 & 18 & 18 & 18 & 18 & 18 & \\
\hline
\end{tabular}

Note: Frequencies includes three oil products (2709-2711) analysed and all GCC countries for a given year. Category ' $\mathrm{A}$ ' denotes the number of non-competitive Balassa index values while 'B'; ' $C$ '; ' $D$ ' categories refer to the number of competitive index values. The total value of the $B$ index categories for 3 product types for 6 countries is 18 per year. 
Table 3 presents the distribution of competitiveness categories, highlighting individual competitiveness levels for certain country-product code pairs within the study period. Apart from outstanding competitiveness for certain pairings (for example Saudi Arabia in crude oil or Qatar in petroleum gases), the dominance of non-competitive indices (category A) is unquestionable, thus it can serve as additional evidence to refute our first hypothesis (H1).

Table 3 Frequency of Balassa index category by Gulf countries between 2000 and 2015

\begin{tabular}{|c|c|c|c|c|c|}
\hline \multirow{2}{*}{ Country } & \multirow{2}{*}{ Product code } & \multicolumn{4}{|c|}{ Count of B index category } \\
\hline & & A & $\mathrm{B}$ & $\mathrm{C}$ & $\mathrm{D}$ \\
\hline United & crude oil & 0 & 11 & 5 & 0 \\
\hline Arab & oil preparations & 12 & 3 & 1 & 0 \\
\hline Emirates & $\begin{array}{c}\text { petroleum } \\
\text { gases }\end{array}$ & 16 & 0 & 0 & 0 \\
\hline \multirow[t]{3}{*}{ Bahrain } & crude oil & 16 & 0 & 0 & 0 \\
\hline & oil preparations & 14 & 2 & 0 & 0 \\
\hline & $\begin{array}{l}\text { petroleum } \\
\text { gases }\end{array}$ & 16 & 0 & 0 & 0 \\
\hline \multirow[t]{3}{*}{ Kuwait } & crude oil & 4 & 12 & 0 & 0 \\
\hline & oil preparations & 11 & 5 & 0 & 0 \\
\hline & $\begin{array}{l}\text { petroleum } \\
\text { gases }\end{array}$ & 16 & 0 & 0 & 0 \\
\hline \multirow[t]{3}{*}{ Oman } & crude oil & 13 & 3 & 0 & 0 \\
\hline & oil preparations & 16 & 0 & 0 & 0 \\
\hline & $\begin{array}{l}\text { petroleum } \\
\text { gases }\end{array}$ & 16 & 0 & 0 & 0 \\
\hline \multirow[t]{3}{*}{ Qatar } & crude oil & 16 & 0 & 0 & 0 \\
\hline & oil preparations & 16 & 0 & 0 & 0 \\
\hline & $\begin{array}{l}\text { petroleum } \\
\text { gases }\end{array}$ & 0 & 6 & 7 & 3 \\
\hline \multirow{4}{*}{$\begin{array}{l}\text { Saudi } \\
\text { Arabia }\end{array}$} & crude oil & 0 & 0 & 3 & 13 \\
\hline & oil preparations & 9 & 7 & 0 & 0 \\
\hline & $\begin{array}{l}\text { petroleum } \\
\text { gases }\end{array}$ & 9 & 7 & 0 & 0 \\
\hline & Total & 200 & 56 & 16 & 16 \\
\hline
\end{tabular}

Source: Own calculations based on World Bank (2017) WITS database

Note: Category ' $A$ ' refers to non-competitive Balassa index values. Category ' $B$ '; ' $C$ ', and ' $D$ ' refer to competitive Balassa index values.

As a result of these factors, the level of competitiveness significantly dropped for all GCC countries, and only three countries (Saudi Arabia, United Arab Emirates and $\mathrm{Ku}$ wait) remained to boast with comparative advantage in oil trade at the end of the study period which was sustained for not more than one oil products in the case of each country. In addition, the distribution of competitiveness categories was also decreasing for all GCC countries for the analysed period. This tendency persuasively suggests that $\mathrm{H} 1$ should be rejected and $\mathrm{H} 2$ partially can be accepted. A tendency of generally diminishing comparative advantage in oil trade for the GCC group was revealed as a consequence of economic, financial, political reasons, including the aftermath of the financial crisis, regional instability, the Syrian conflict, fluctuating international oil prices.

The GCC economies still rely on oil as the main source of export and fiscal revenues but they have to establish the non-oil economy that will be needed in the future when oil revenues start to drop (IMF 2014).

The EU aims to reduce their reliance on external suppliers of oil and gas for 2020 (EC, 2018), thus, decreasing consumption of crude oil and its derived products will be expected in the future.

From Hungarian aspects, investing in new technologies; widening crude oil portfolio; transforming production from fuel to non-fuel products can be expected in the future (MOL, 2018). Therefore, the demand for GCC's oil products might fall down in the next decades.

\section{Conclusions and discussion}

Based on a quantitative analysis conducted with comparative advantage measures (RCA indices), only four out of six GCC member states (Kuwait, the Kingdom of Saudi Arabia, United Arab Emirates, and Qatar) were found to possess an initial competitive status for at least one oil product of the three analysed product category, which clarifies the fact that $\mathrm{H} 1$ hypothesis needs to be rejected.

However, a tendency of generally diminishing comparative advantage in oil trade for the GCC group was revealed as consequence of a handful of economic, financial, political reasons, including the aftermath of the financial crisis in 2008, regional instability, fluctuating international oil price levels (H2). As a result of these factors, the level of competitiveness significantly dropped for all GCC countries, and only three countries (Saudi Arabia, United Arab Emirates and Kuwait) remained to boast with comparative advantage in oil trade at the end of the study period (which was sustained for not more than one oil products in the case of each country).

In light of the study outcome, our suggestions for GCC member states - to keep their current positions in the league of developed oil trader countries - would be as follows:

Carry on and broaden the pool of efforts devoted to mitigating their present excessive exposure to the oil industry. Since most of these countries have already launched long term national projects aiming at economic diversification, what they need now is only the enforcement of adherence to the cornerstones already laid down in these visions.

GCC societies should foster tighter cooperation with each other. These countries already realized that they have many things common, which facilitates maintaining a cooperative and mutually assistive approach. For instance, sharing the same culture and language opens the doors of making further steps towards a more centralized law enforcement and bureaucracy, which is bound to be more costefficient than what these elements of statehood cost today.

Stagnation of oil prices at low levels and falling energy demand of the EU and the World has compelled these countries lately to give up their squandering social benefit provi- 
sion policy, which - is going forth along the same lines - is a measure that undoubtedly contributes to a healthier economic structure.

Finally, it should be noticed that our study also has some limitation. Trade values required to perform computations of Balassa indices were missing in some cases, which had to be handled in applying substitution of missing values by 0 (in that case zero trade flows were assumed). The model of the revealed comparative advantage assumes homogenous products traded and perfect competition in international markets. The deviation of market conditions from perfection might provide directions for future research.

\section{References}

Acin, Đ. (1974): A nemzetközi kereskedelem elméletének áttekintése és elemzése. Létünk, 3(1), pp. 1-179.

Ajluni, S. (2003): The Palestinian Economy and the Second Intifada. Journal of Palestine Studies, 32(3), pp. 64-73. https://doi.org/10.1525/jps.2003.32.

Almas, L. K. - Hajiyev, N. U. (2013): Azerbaijan's Current and Potential Comparative Advantage: An Exploratory Study (Publication). Selected Paper prepared for presentation at the International Conference on Policy Modeling (EcoMod 2013) Prague, Czech Republic, July 1-3, 2013.

AlQudah, A. - Badawi, A. - AboElsoud, M. E. (2016): The Impact of Oil Sector on the Global Competitiveness of the GCC Countries: Panel Data Approach. Research Journal of Finance and Accounting, 7(20), pp. 32-39. ISSN 2222-2847

Ádám, D. - Bodnár, L. - Luspay, M. (2015): Iszlám bankrendszer az Egyesült Arab Emírségekben. Hitelintézeti Szemle, 14(Special edition), pp. 72-89. Retrieved from http://www.hitelintezetiszemle.hu/letoltes/6adam-bodnar-luspay-miklos.pdf

Balassa, B. (1965): Trade Liberalisation and "Revealed" Comparative Advantage. The Manchester School, 33(2). https://doi.org/10.1111/j.1467-9957.1965.tb00050.x

$B B C$ (2016a): Syria: The story of the conflict. (2016, March 11). Retrieved April 26, 2017, from http://www.bbc. com/news/world-middle-east-26116868

$B B C$ (2016b): United Arab Emirates country profile. (2016, September 28). Retrieved April 25, 2017, from http://www.bbc.com/news/world-middle-east-14703998

$B B C$ (2015): What is 'Islamic State'? (2015, December 2). Retrieved April 26, 2017, from http://www.bbc.com/ news/world-middle-east-29052144

Bernstein, W. J. (2008): A Splendid Exchange: How Trade Shaped the World. Atlantic Monthly Press, New York, 2008. ISBN-10: 184354668X

$B P$ (2016): British Petroleum Company statistical review of world energy. London: British Petroleum Co. Retrieved March 13, 2017, from https://www.bp.com/content/ $\mathrm{dam} / \mathrm{bp} / \mathrm{pdf} /$ energy-economics/statistical-review-2016/bpstatistical-review-of-world-energy-2016-full-report.pdf

CAPP (2017): Canadian Association of Petroleum Producers Canada's Oil Sands. Retrieved April 25, 2017, from http://www.canadasoilsands.ca/en/

Crude Oil Prices (2017): 70 Year Historical Chart. Retrieved March 13, 2017, from http://www.macrotrends. net/1369/crude-oil-price-history-chart
EC (2018) European Commission Energy Efficiency Retrieved January 2019, 28 from https://ec.europa.eu/energy/en/topics/energy-efficiency

EIA (2013): Energy Information Administration (US). (2013, July 8). Kuwait. Retrieved May 8, 2017, from http://www.europarl.europa.eu/meetdocs/2009_2014/ documents/darp/dv/darp20140213_11_/darp20140213_11_ en.pdf

EIA (2015): Energy Information Administration (US). (2015, August 6). Russia is world's largest producer of crude oil and lease condensate. Retrieved May 3, 2017, from https://www.eia.gov/todayinenergy/detail.php?id=22392

EIA (2016): Energy Information Administration (Beta). (2016, January 28). Oman. Retrieved May 8, 2017, from https://www.eia.gov/beta/international/analysis. cfm?iso $=\mathrm{OMN}$

GCC (2017): Secretariat General of the Gulf Cooperation Council: The Cooperation Council for the Arab States of the Gulf homepage. About GCC: Objectives Retrieved March 18, 2017, from http://www.gcc-sg.org/en-us/AboutGCC/Pages/StartingPointsAndGoals.aspx

Hinloopen, J. - van Marrewijk, C. (2001): On the empirical distribution of the Balassa Index Welwirtschaftlishes Archiv 137(1), pp. 1-35. Retrieved from http://www2.econ. uu.nl/users/marrewijk/eta/pdf\%20files/ballassa $\% 20$ wwa. pdf

Huggins, R. - Mahroum, S. - Thompson, P. (2016): The Middle East Competitiveness Report: Regional and Territorial Analysis (Rep.). Cardiff University, INSEAD, Nottingham Business School. Retrieved May 2017, 13 from https:/centres.insead.edu/innovation-policy/publications/ documents/MiddleEastCompetivenessReport2016.pdf

IMF (2014) Stuff Discussion Note. Economic Diversification in the GCC: Past, Present, and Future Retrieved January 2019, 28 from https://www.imf.org/external/pubs/ $\mathrm{ft} / \mathrm{sdn} / 2014 / \mathrm{sdn} 1412 . \mathrm{pdf}$

Jámbor, A. (2009): A magyar gabonafélék és feldolgozott termékeinek komparatív előnyei és versenyképessége az EU-15 országainak piacain. Közgazdasági Szemle, 56(5), pp. 443-463. Retrieved from http://www.epa. hu/00000/00017/00159/pdf/03muhely_jambor.pdf

Jáni, A. (2011): Az iraki háború előzményei és az intervenció hatása a nemzetközi politikára. Szakdolgozat. Budapest: Budapesti Gazdasági Főiskola. Külkereskedelmi Föiskolai Kar

Jones, P. (2012): The Arab Spring: Opportunities and implications. International Journal: Canada's Journal of Global Policy Analysis 67(2), pp. 447-463. https://doi. org/10.1177/002070201206700214

Lövész, G. (2006): OPEC. Szakdolgozat. Budapest: Budapesti Gazdasági Főiskola. Külkereskedelmi Főiskolai Kar

Mikesy, Á. (2009): A fekete arany nyomában. Scientific TDK article. Budapesti Corvinus Egyetem. Retrieved April 28, 2017, from http://szd.lib.uni-corvinus.hu/1715/

MOL (2018) MOL Group Homepage. Strategy 2030 Retrieved 28 January, 2019, form https:/molgroup.info/ strategy2030/

Norwegian Petroleum (2017): Retrieved April 25, 2017, from http://www.norskpetroleum.no/en/ 
Saudi Arabian Monetary Authority (2016): Annual Statistics. Retrieved April 25, 2017, from http://www. sama.gov.sa/en-US/EconomicReports/Pages/YearlyStatistics.aspx

Siggel, E. (2006): International competitiveness and comparative advantage: A survey and a proposal for measurement. Journal of Industry, Competition and Trade, 6(2), pp. 137-159. Retrieved from https://link.springer.com/article/10.1007/s10842-006-8430-x

Smith, A. (1776): An inquiry into the Nature and Causes of the Wealth of Nations. MetaLibri, Lausanne 29 May 2007. Retrieved April 25, 2017, from https:/www.ibiblio. org/ml/libri/s/SmithA_WealthNations_p.pdf

Somogyi, M. (2009): Versenyképesség a szakirodalomban - A fogalmi megközelítések összegzése és elemzése (I. rész). Vezetéstudomány - Budapest Management Review, 40 (4), pp. 54-64.

Szücs, F. K. (2007): A kőolaj hajnala, aranykora és alkonya. Természet Világa, 138(1), pp. 13-16.
Talal-Azimi, R. (2016): Bahrain: Structural adjustments are necessary to mitigate the impact of low oil prices (Rep.). Rabo Research Global Economics \& Markets. Retrieved May 05, 2017, from: https://economics. rabobank.com/publications/2016/june/bahrain-structuraladjustments-are-necessary-to-mitigate-the-impact-oflow-oil-prices/

Tomolya, J. (2007): A „34 napos” izraeli-libanoni háború (Rep.). Retrieved March 13, 2017, from: https:// anzdoc.com/a-34-napos-izraeli-libanoni-haboru.html

Vivoda, V. (2012): Japan's energy security predicament post-Fukushima. Energy Policy, 46, pp. 135-143. https:// doi.org/10.1016/j.enpol.2012.03.

Weiss, B. G. - Green, A. H. (1995): A Survey of Arab History. Cairo, Egypt: The American University Press. ISBN 9774241800 (pbk.)

World Bank (2017): World Integrated Trade Solutions (WITS) database. Retrieved March 13, 2017, from: https:// wits.worldbank.org/WITS

\section{Appendix}

\section{Individual B-index results for oil trade for GCC countries}

\begin{tabular}{|c|c|c|c|c|c|c|c|c|c|c|c|c|c|c|c|c|c|}
\hline product code & Country & 2000 & 2001 & 2002 & 2003 & 2004 & 2005 & 2006 & 2007 & 2008 & 2009 & 2010 & 2011 & 2012 & 2013 & 2014 & 2015 \\
\hline cruc & $\begin{array}{l}\text { United Arab } \\
\text { Emirates }\end{array}$ & 2.64 & 2.55 & 1.98 & 9 & 10 & 04 & 66 & 1.82 & 1.46 & 1.50 & 1.47 & 1.25 & 1.40 & 1.13 & 1.14 & 1.26 \\
\hline arations & $\begin{array}{l}\text { United Arab } \\
\text { Emirates }\end{array}$ & 1.24 & 1.15 & 2.13 & 0.88 & 1.25 & 0.79 & 0.90 & 0.81 & 0.66 & 0.82 & 0.23 & 0.23 & 0.21 & 0.51 & 0.50 & 0.57 \\
\hline $\begin{array}{l}\text { petroleum } \\
\text { gases }\end{array}$ & $\begin{array}{l}\text { United Arab } \\
\text { Emirates }\end{array}$ & 0.89 & 0.89 & 0.48 & 0.17 & 0.14 & 0.27 & 0.30 & 0.30 & 0.00 & 0.66 & 0.18 & 0.14 & 0.41 & 0.37 & 0.40 & 0.40 \\
\hline crude oil & Bahrain & 0.00 & 0.00 & 0.00 & 0.00 & 0.00 & 0.00 & 0.00 & 0.00 & 0.00 & 0.00 & 0.00 & 0.00 & 0.00 & 0.00 & 0.00 & 0.00 \\
\hline oil preparations & Bahrain & 1.14 & 1.12 & 1.12 & 0.97 & 0.72 & 0.66 & 0.52 & 0.55 & 0.25 & 0.28 & 0.42 & 0.35 & 0.22 & 0.19 & 0.20 & 0.21 \\
\hline petroleum gases & Bahrain & 0.00 & 0.00 & 0.00 & 0.00 & 0.00 & 0.00 & 0.00 & 0.00 & 0.00 & 0.00 & 0.00 & 0.00 & 0.00 & 0.00 & 0.00 & 0.00 \\
\hline crude oil & Kuwait & 1.34 & 1.47 & 1.13 & 1.14 & 1.22 & 0.00 & 1.13 & 1.19 & 1.05 & 1.02 & 0.83 & 0.93 & 0.00 & 1.02 & 1.09 & 1.27 \\
\hline oil preparations & Kuwait & 1.56 & 1.38 & 1.48 & 1.35 & 1.15 & 0.00 & 0.82 & 0.94 & 0.64 & 0.82 & 0.69 & 0.57 & 0.00 & 0.47 & 0.48 & 0.53 \\
\hline $\begin{array}{l}\text { petroleum } \\
\text { gases }\end{array}$ & Kuwait & 0.40 & 0.39 & 0.33 & 0.29 & 0.30 & 0.00 & 0.22 & 0.23 & 0.18 & 0.20 & 0.23 & 0.18 & 0.00 & 0.16 & 0.11 & 0.17 \\
\hline crude oil & Oman & 1.05 & 1.17 & 1.02 & 0.82 & 0.67 & 0.66 & 0.44 & 0.44 & 0.40 & 0.48 & 0.47 & 0.38 & 0.45 & 0.41 & 0.55 & 0.65 \\
\hline oil preparations & Oman & 0.06 & 0.02 & 0.01 & 0.03 & 0.02 & 0.02 & 0.01 & 0.08 & 0.08 & 0.04 & 0.05 & 0.01 & 0.07 & 0.03 & 0.05 & 0.09 \\
\hline $\begin{array}{l}\text { petroleum } \\
\text { gases }\end{array}$ & Oman & 0.00 & 0.59 & 0.57 & 0.32 & 0.43 & 0.41 & 0.41 & 0.44 & 0.32 & 0.32 & 0.22 & 0.13 & 0.22 & 0.19 & 0.26 & 0.01 \\
\hline crude oil & Qatar & 0.46 & 0.86 & 0.40 & 0.67 & 0.63 & 0.65 & 0.49 & 0.59 & 0.47 & 0.54 & 0.45 & 0.36 & 0.38 & 0.32 & 0.34 & 0.39 \\
\hline oil preparations & Qatar & 0.05 & 0.06 & 0.16 & 0.17 & 0.15 & 0.00 & 0.09 & 0.08 & 0.05 & 0.08 & 0.21 & 0.17 & 0.18 & 0.14 & 0.13 & 0.14 \\
\hline $\begin{array}{l}\text { petroleum } \\
\text { gases }\end{array}$ & Qatar & 1.80 & 2.07 & 1.87 & 1.60 & 1.70 & 1.56 & 1.58 & 2.04 & 2.33 & 2.21 & 3.72 & 3.91 & 4.40 & 3.83 & 4.14 & 4.54 \\
\hline crude oil & Saudi Arabia & 7.44 & 7.80 & 7.60 & 7.02 & 6.81 & 6.90 & 4.98 & 5.49 & 4.48 & 4.90 & 4.27 & 3.86 & 4.43 & 3.80 & 3.95 & 4.82 \\
\hline oil preparations & Saudi Arabia & 1.31 & 1.94 & 1.56 & 1.50 & 1.67 & 1.55 & 1.01 & 0.89 & 0.63 & 0.79 & 0.66 & 0.52 & 0.50 & 0.36 & 0.54 & 0.71 \\
\hline petroleum & Saudi Arabia & 1.73 & 1.24 & 1.53 & 1.41 & 1.24 & 1.06 & 0.96 & 1.07 & 0.72 & 0.67 & 0.63 & 0.45 & 0.43 & 0.34 & 0.33 & 0.37 \\
\hline gases & & & & & & & & & & & & & & & & & \\
\hline
\end{tabular}

Source: own calculation based on sample data 